\title{
Correction to: Spatial distribution and estimation of rainfall trends and erosivity in the Epitácio Pessoa reservoir catchment, Paraíba, Brazil
}

\author{
Richarde Marques da Silva ${ }^{1}$ (D) . Celso Augusto Guimarães Santos ${ }^{2}$ (D) . \\ Jorge Flávio Casé Braga da Costa Silva ${ }^{3}$ (D) . Alexandro Medeiros Silva ${ }^{3}$. \\ Reginaldo Moura Brasil Neto ${ }^{4}$ (D)
}

Published online: 16 September 2020

(C) The Author(s) 2020

\section{Correction to: Natural Hazards (2020) 102:829-849 https://doi.org/10.1007/s11069-020-03926-9}

The article "Spatial distribution and estimation of rainfall trends and erosivity in the Epitácio Pessoa reservoir catchment, Paraíba, Brazil", written by da Silva, R.M., Santos, C.A.G., Silva, J.F.C.B.C., et al, was originally published Online First without Open Access. After publication in volume 102 , issue 3, pages 829-849, the author decided to opt for Open Choice and to make the article an Open Access publication. Therefore, the copyright of the article has been changed to (C) The Author(s) 2020 and the article is forthwith distributed under the terms of the Creative Commons Attribution 4.0 International License, which permits use, sharing, adaptation, distribution and reproduction in any medium or format, as long as you give appropriate credit to the original author(s) and the source, provide a link to the Creative Commons licence, and indicate if changes were made. The images or other third-party material in this article is included in the article's Creative Commons licence, unless indicated otherwise in a credit line to the material. If material is not included in the article's Creative Commons licence and your intended use is not permitted by statutory regulation or exceeds the permitted use, you will need to obtain permission directly from the copyright holder. To view a copy of this licence, visit http://creativecommons.org/licen ses/by/4.0.

The original article can be found online at https://doi.org/10.1007/s11069-020-03926-9.

Celso Augusto Guimarães Santos

celso@ct.ufpb.br

1 Department of Geosciences, Federal University of Paraíba, João Pessoa PB 58051-900, Brazil

2 Department of Civil and Environmental Engineering, Federal University of Paraíba, João Pessoa PB 58051-900, Brazil

3 Postgraduate Programme Geography/CCEN/UFPB, Federal University of Paraíba, João Pessoa PB 58051-900, Brazil

4 Postgraduate Programme Civil and Environmental Engineering/CT/UFPB, Federal University of Paraíba, João Pessoa PB 58051-900, Brazil 
Open Access This article is licensed under a Creative Commons Attribution 4.0 International License, which permits use, sharing, adaptation, distribution and reproduction in any medium or format, as long as you give appropriate credit to the original author(s) and the source, provide a link to the Creative Commons licence, and indicate if changes were made. The images or other third party material in this article are included in the article's Creative Commons licence, unless indicated otherwise in a credit line to the material. If material is not included in the article's Creative Commons licence and your intended use is not permitted by statutory regulation or exceeds the permitted use, you will need to obtain permission directly from the copyright holder. To view a copy of this licence, visit http://creativecommons.org/licenses/by/4.0/.

Publisher's Note Springer Nature remains neutral with regard to jurisdictional claims in published maps and institutional affiliations. 